\title{
METHOD FOR SHALLOW DRAINAGE DITCH NETWORK GENERATION USING REMOTE SENSING DATA
}

\author{
Raitis MELNIKS, Latvian State Forest Research Institute "Silava", Riga street 111, Salaspils, Latvia, LV-2169, \\ raitis.melniks@silava.lv (corresponding author) \\ Janis IVANOVS, Latvian State Forest Research Institute "Silava", Riga street 111, Salaspils, Latvia, LV-2169, \\ janis.ivanovs@silava.lv \\ Andis LAZDINS, Latvian State Forest Research Institute "Silava", Riga street 111, Salaspils, Latvia, LV-2169, \\ andis.lazdins@silava.lv
}

\begin{abstract}
Aim of this study is to develop a method for automatic shallow drainage ditch generation to drain terrain depressions using four factor least cost surface which is obtained using LiDAR (light detection and ranging) data and Sentinel-2 multispectral satellite imagery. LiDAR data are used for depression mapping in DEM, flow accumulation and slope modelling as well as CHM (canopy height model) to obtain relative vegetation height. Sentinel-2 imagery was used for land cover type identification as well as separating coniferous and deciduous forest stands. Study area is located in western Latvia and is $25 \mathrm{~km}^{2}$ large. Least cost surface connects DEM depressions and already existing drainage ditches by best possible path for shallow ditch network digging. Different methods are applied to determine depressions which can be drained as well as changes of affected drained area and depression depth. This results in suitable areas where to create shallow ditches to improve water runoff. Results show that using this method average reduction of area of depressions is $79 \%$ and average length of shallow ditches on each drained depression hectare is $370 \mathrm{~m}$.
\end{abstract}

Keywords: forest drainage, depression, cost surface

\section{INTRODUCTION}

Several studies point to significant changes in the index values of extreme climatic phenomena in Europe since the mid-20th century. They point to an increase in economic losses caused by weather and climatic conditions, and it is expected that further climate change will exacerbate these negative impacts on different socio-economic sectors (Handmer et al., 2012; Kovats et al., 2014). One example is forestry, where wet soil conditions limit the growth of trees and the negative impact on soil from movement of logging machinery is increased. It is important to improve existing drainage systems or create new ones to improve the tree growth conditions in places where it is needed (Skaggs et al. 2016). Thereby information about exact spatial distribution of wet mineral and organic soils is important for both sustainable forest management and research (Moore et al. 1991; Ivanovs et al. 2018). This type of information helps to improve sustainable land management practices, avoids financial losses, and reduces the environmental risks of economic activity (Christensen et al. 1996).

Poorly drained and wet soils are a challenge for forestry, agriculture and other industries (McNabb et al. 2001). Surface topography and soil parent material are the main factors determining the formation of wet soil conditions. Surface topography determines runoff, hydrological network connectivity and water accumulation (Jencso et al. 2009). The surface and groundwater flow almost always coincide with the direction of the terrain slope (Zinko et al. 2005). Soil moisture in the depressions determines the physiological processes of plants and the exchange of substances in tree root systems and increases mortality of the roots of trees (Laine et al., 1995). For example, mortality of pine and spruce roots begins when they are flooded within 3-5 days but recovers only in 2-4 weeks when the groundwater level decreases depending on the degree of damage. For pine stands, this process is faster due to their improved adaptation to wet conditions (Zalitis, 2012). It is difficult to predict spatial distribution of soil properties due to their variability and diversity, as well as the different environmental factors (Burrough et al. 1997). Topography is one of the most important factors that affect the hydrological condition. It affects the spatial distribution of the water flow direction and soil moisture.

Surface water drainage is required in regions where precipitation exceeds evaporation, and in areas where soil drainage and sediment properties do not ensure the drainage of surface water (Kozlowski 2002). The overriding objectives of water abstraction are to achieve higher forest stand productivity, improve growth conditions, provide access to forest stands and to create suitable conditions for forest regeneration and logging. Particular attention

Copyright (C) 2019 The Authors. Published by Vytautas Magnus University. This is an open-access article distributed under the terms of the Creative Commons Attribution License (CC BY 4.0), which permits unrestricted use, distribution, and reproduction in any medium, provided the original author and source are credited. 
should be paid to peat soils with high groundwater levels (Peltomaa 2007). After amelioration, the length of time in which timber can be carried out without damage to the soil is prolonged without leaving deep ruts (Skaggs et al. 2016). It is considered that after the area is drained, tree growth in the spring begins earlier than in wet areas. This is the result of comparing the growth rate of different forest types (Zālītis 2012). Open ditch building is a common practice in forestry and agriculture. They are less expensive than pipe drains, but there is a higher risk of erosion in open ditches. Formation shallow ditches, up to 0.4 meters deep, is becoming increasingly popular rather than digging large drainage ditches (Haapalehto 2011). Formation of shallow ditches is done to lower groundwater level and water from relief depressions in forest stands. (Piirainen et al. 2017). The excess water from the forest stands is discharged before or after logging (Lohmus et al. 2015).

\section{MATERIALS AND METHODS}

Study area is $25 \mathrm{~km}^{2}$ large, located in western part of Latvia (Fig. 1) and selected to represent different types of relief formations and quaternary deposits (glacigen, glaciolacustrine, glaciogluvial, eolian). LiDAR data for this study is obtained from Latvian Geospatial Information agency (LGIA), multispectral satellite imagery - European Space Agency (ESA), forest stand vector data from State Forest Service (SFS) database, ditch and culvert vector data from Latvian State Forests (LSF) database. LiDAR data point density is $4-12$ points in total and at least 1.5 ground points per $\mathrm{m}^{2}$ with an average horizontal point error of $0.36 \mathrm{~m}$ and vertical accuracy of $0.12 \mathrm{~m}$ (LGIA 2016).

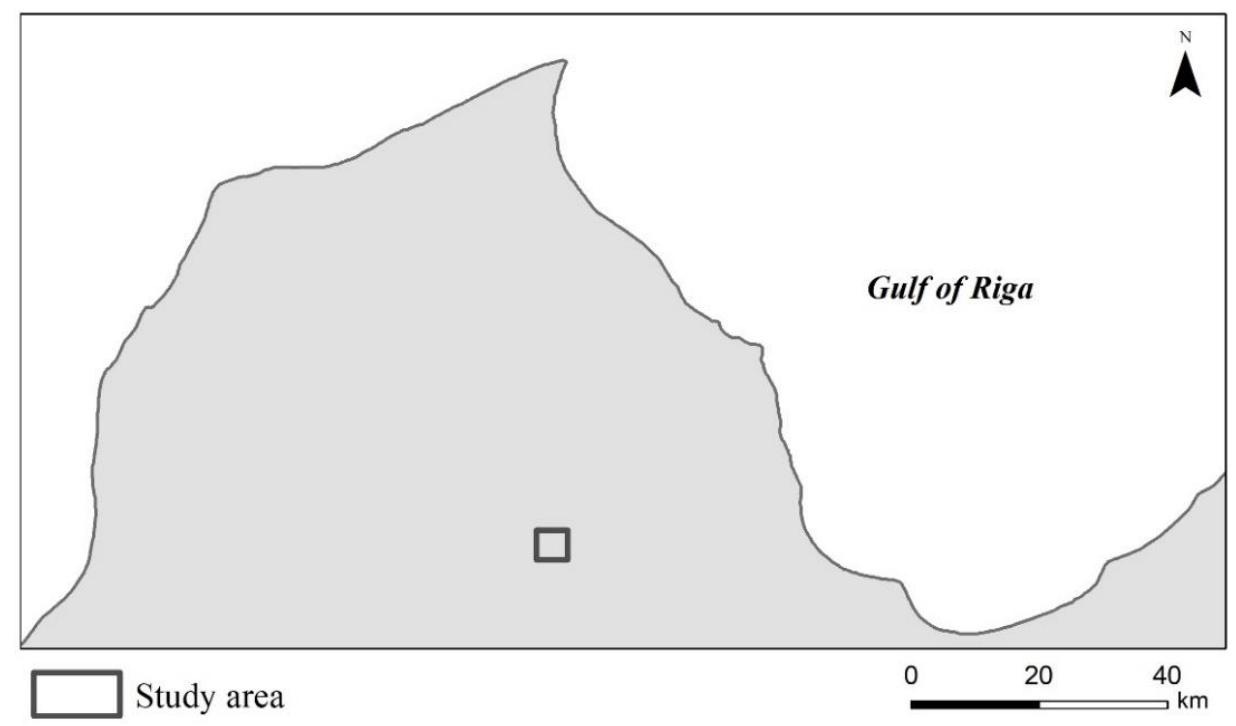

Figure 1. Schematic emplacement of study area.

Method is developed on various DEM (Digital elevation model) and CHM (Canopy height model) transformations as well as multispectral satellite imagery classification basis which are used to make three factor cost surface. Digital elevation model for study area was created using GRASS GIS tool r.ln.lidar and interpolated with r.fillnulls algorithm in resolutions 1 and $3 \mathrm{~m}$. Canopy height model was created in $1 \mathrm{~m}$ resolution using DEM and digital surface model (DSM) in same $1 \mathrm{~m}$ resolution using GRASS GIS 7.6 software. Whitebox software tool Burn Streams at Roads was used to smooth out road artifacts over stream crossings using ditch and culvert vector data to make possible water flow modelling on DEM.

SAGA GIS algorithm Fill Sinks (Wang\&Liu) (Wang, Liu 2006) is used to identify surface depressions in forest. It is an algorithm that is often used in hydrological modelling to discern flow direction. Raster map of depressions is generated by extracting original DEM from filled DEM. Resulting raster map contains information about spatial distribution and depth of depressions in given area. According to previous studies in Latvia, soil wetness is more likely to increase in depressions which are at least $4 \mathrm{~cm}$ deep (Ivanovs, Lupikis 2018). Depression raster map is converted to polygon vector data format using GRASS GIS tool r.contour to outline depressions which are at least $0.1 \mathrm{~m}$ deep. In this study, we assume that only depressions which are at least $300 \mathrm{~m}^{2}$ will be drained. As shown in Fig. 2. centroid is added to each depression polygon, which will be starting point for shallow drainage ditch. 


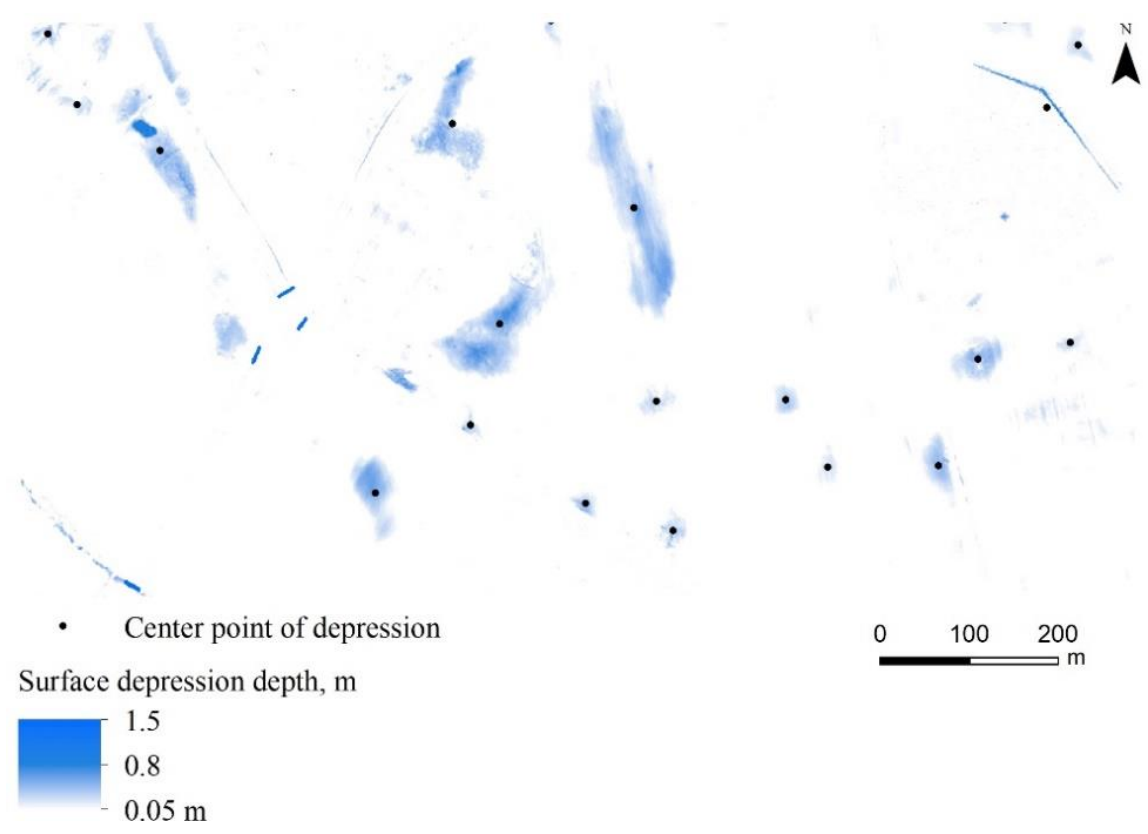

Figure 2. Example of spatial distribution of surface depressions in forest.

For surface flow modelling GRASS GIS tool r.watershed using Flow accumulation algorithm Multiple flow direction (MFD) method was used. Input DEM is given in $3 \mathrm{~m}$ resolution. With MFD, water flow is distributed to all neighboring cells with lower elevation, using slope towards neighboring cells as a weighing factor for proportional distribution (Holmgren 1994). One factor which is used in cost surface is made using obtained flow accumulation raster map using equation (1).

$$
\log X
$$

where $\mathrm{X}$ is flow accumulation raster map. Resulting map is reclassified to values from 1-14.

Canopy height model (CHM) was made extracting DEM from DSM in $1 \mathrm{~m}$ resolution. Obtained CHM are smoothed using sliding window principle. Each cell is assigned a value that corresponds to the average value of $\mathrm{CHM}$ within 24 neighboring cells. Resulting raster map represents more homogenous forest stand height, which is used to obtain second factor in cost surface. Using raster algebra, values are divided by 4 to obtain values from 1-10.

There is significant difference between coniferous and deciduous trees in near infrared spectrum (Immitzer et al. 2016). Sentinel-2 satellite imagery is used in this study to detect land cover type in 3 categories - deciduous and coniferous trees as well as all other land cover types in one category. It was done calculating Normalized Difference Vegetation Index (NDVI) with raster algebra using equation (2).

$$
N D V I={ }_{N I R+V I S}^{N I R}
$$

where NIR - near infrared spectral band; VIS - visible red spectral band. ArcGIS 10.6 tool Supervised image classification was used to classify NDVI and NIR raster map combination. Obtained land cover raster map is reclassified for least cost surface - coniferous forest stand corresponds to 8 , deciduous -5 , other type -1 . Least cost surface is calculated using simple raster algebra, counting three raster maps together obtaining surface with values from 3 to 32 , where smaller value is more likely to be path for shallow drainage ditch.

When main cost surface which contains reclassified values from three factors, mentioned before is made as shown in Fig. 3, ArcGIS 10.6 tool Cost Distance is used. This tool calculates the least accumulative cost distance for each cell to the nearest source over a cost surface. In our case this source is existing drainage ditches (Fig 3.). When it comes to this part, it is very important to have correct and complete input surface drainage data, because this algorithm uses it as a reference, where to link shallow drainage ditches, which will be generated.

Obtained cost-distance surface which are attached to existing surface drainage system is processed using GRASS GIS tool r.drain, which traces a least cost flow through an elevation model or cost surface on a raster map starting from given points. In our case, these points are obtained before and corresponds to the centers of surface depressions. It is expected, that shallow ditch patterns will be traced to evade mature forest stands, especially coniferous as well as areas which are far from natural surface flow. 


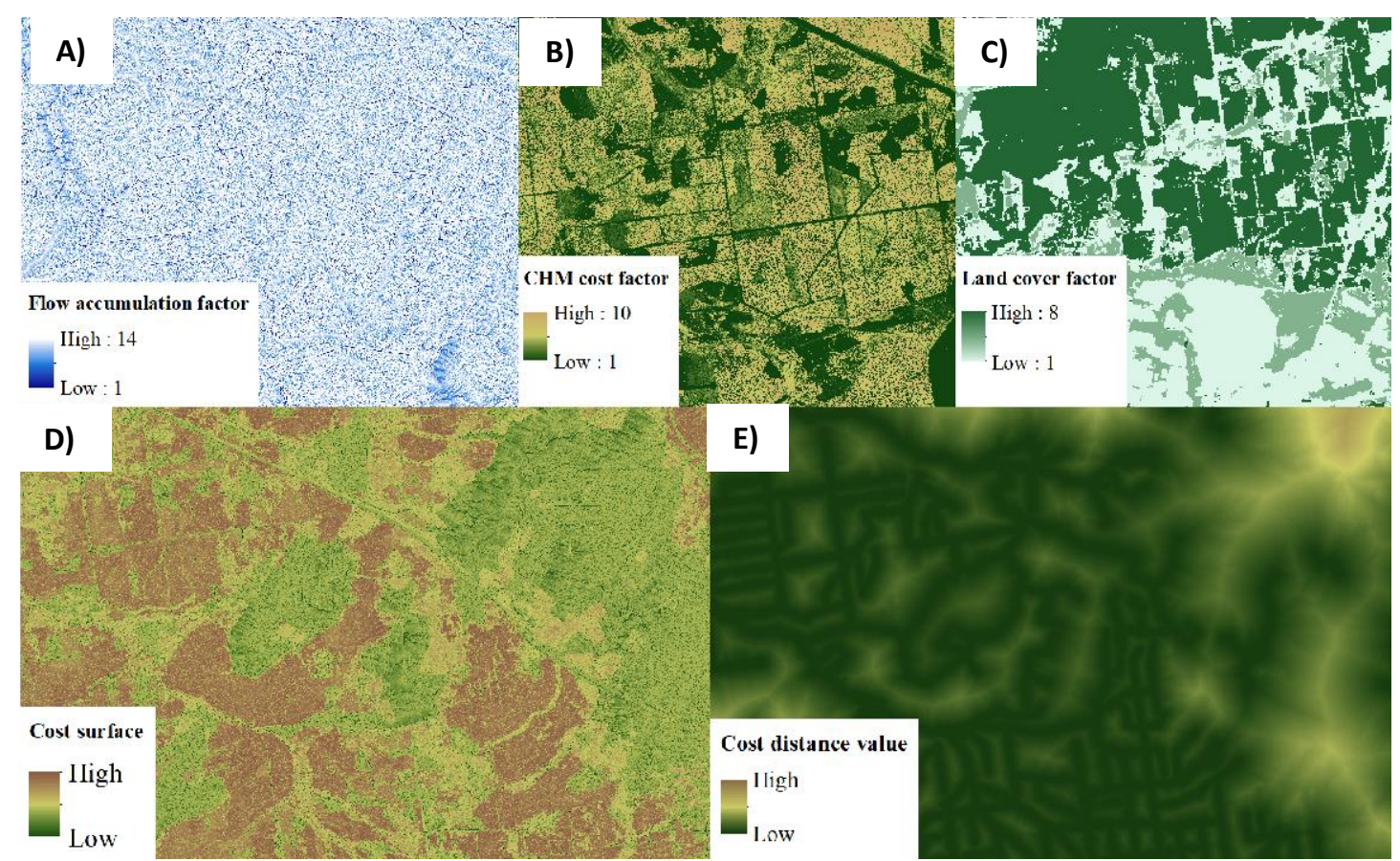

Figure 3. A) - Flow accumulation cost factor; B) CHM cost factor; C) - Land cover cost factor; D) - Least cost surface obtained counting A) + B) + C); E) Cost distance surface, where least cost surface is attached to existing drainage ditches.

Output data of previous process is generated shallow ditch patterns, leading from center of surface depression to nearby ditch or channel, which are given in both raster and vector data format. Generated ditch network is verified by burning it in to the digital elevation model and analyzing changes in depth and area of surface depression. In this study r.carve is used and depth of ditch is set to $0.4 \mathrm{~m}$ and width to $1 \mathrm{~m}$ which is same as DEM resolution.

After ditch burning in DEM, Fill sinks with carved DEM as input is used to estimate changes of area and depth of depressions. It is done comparing differences in each depression by two factors mentioned before. If difference in depth and area is less than $20 \%$ - shallow ditch pattern is deleted and depression is considered as undrainable by method with shallow ditches.

\section{RESULTS AND DISCUSSION}

To analyze obtained results, we use filled surface depression area and depth before any manipulations and compare them with area after burning shallow ditches. The length of generated ditches is used to estimate approximate carving efficiency on affected area.

Acquired results, according to Fig. 4 and Fig. 5., show that there is significant difference in area of depressions before and after burning shallow ditches in DEM. Area of depressions moderately decreases by $79 \%$, using 265 depressions from our study area. Total area of all depressions is 108 ha and after processing total area decreases to 22,68 ha. From total count of depressions, 97 was fully drained or the area were smaller than $30 \mathrm{~m}^{2}$. This result is obtained by generating $35,26 \mathrm{~km}$ of shallow ditches. Average length of shallow ditch connecting main ditch and depression was 133 $\mathrm{m}$ and for each ha there are $370 \mathrm{~m}$ od shallow ditches.

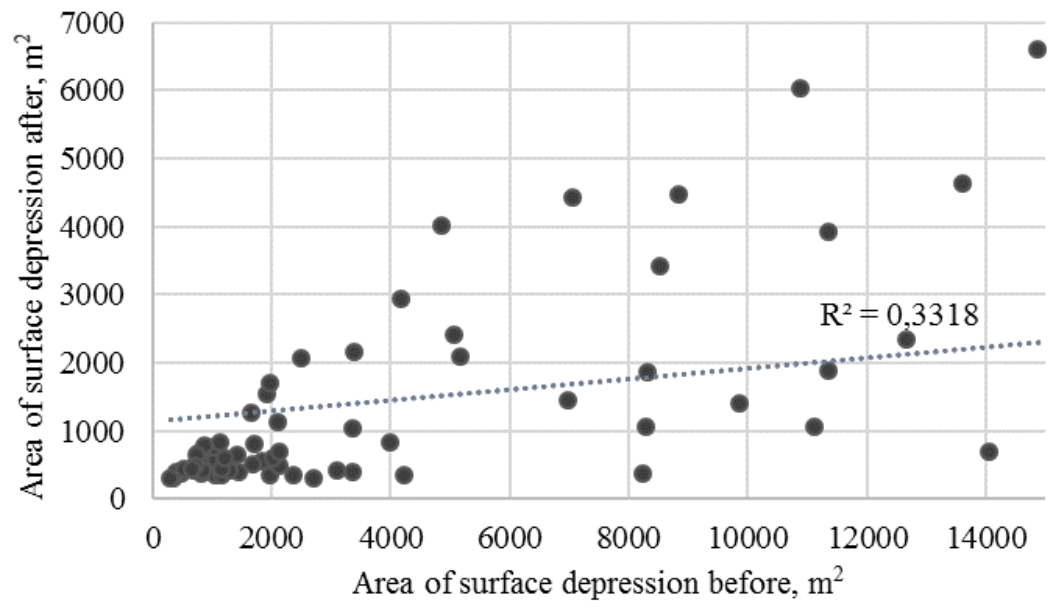

Figure 4. Comparison of surface depression are before and after modeling ditches. 
According to studies in Sweden (Skaggs et al. 2016), shallow ditch network density is approximately $400 \mathrm{~m}$ on average on each drained ha, but we couldn't find similar studies, where shallow ditches are made and results spatially analyzed in context of depression drainage as main reason. These numbers from Sweden, where shallow ditches in forest are common tells that our method can be used in praxis and won't dramatically increase ditch density and related ecological impacts.

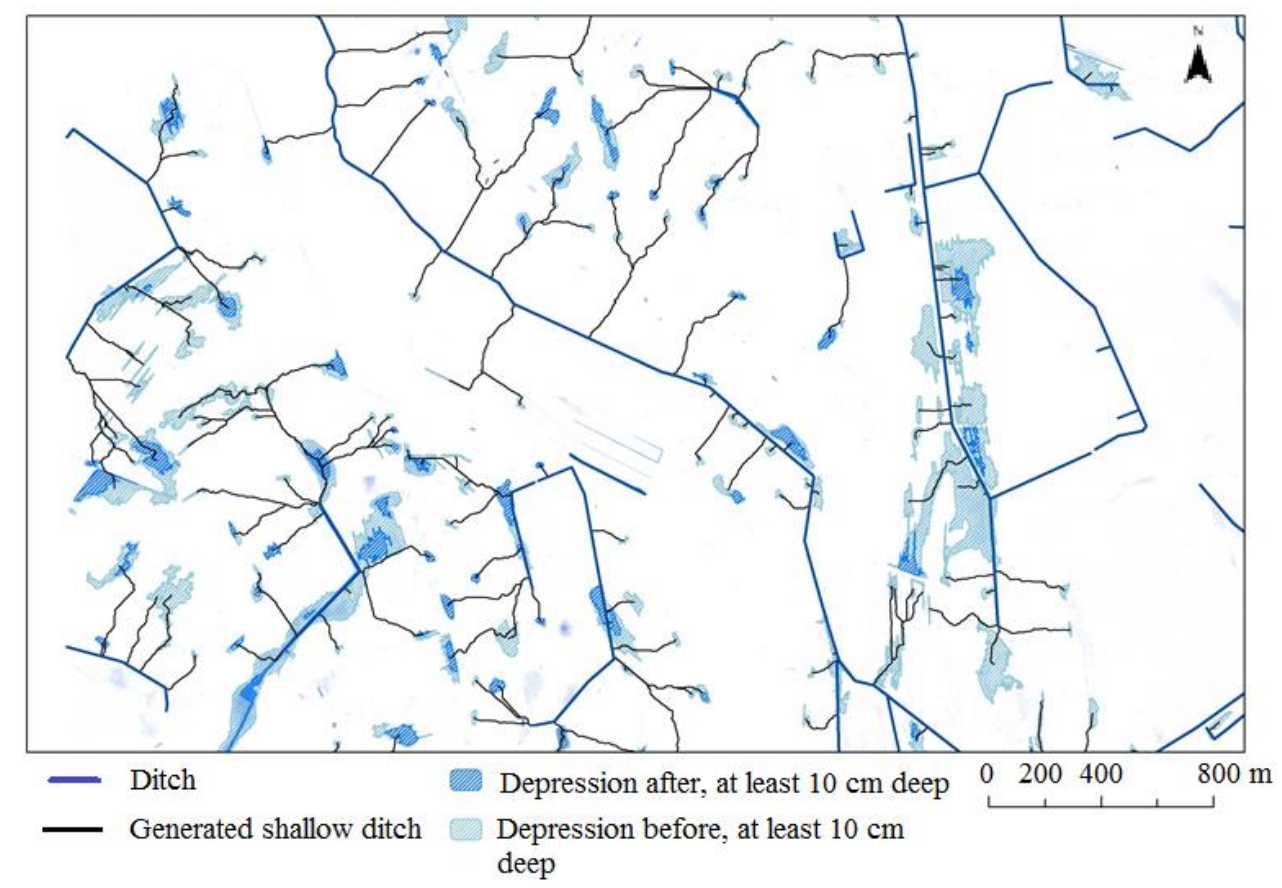

Figure 5. Example of generated shallow ditches and differences before and after applying method.

\section{CONCLUSIONS}

1. Using this method, it is possible to plan forest depression drainage. In our case average reduction of depression area was $79 \%$;

2. Usage of this method is limited in fragmented terrain with different types of relief shapes which have large elevation difference;

3. For best results, used method requires complete and correct existing drainage system data.

Acknowledgements. The study was implemented within the scope of the Forest Sector Competence Centre of Latvia - No. 1.2.1.1/18/A/004 P11 „Elaboration of guidelines and modelling tool for greenhouse gas (GHG) emission reduction in forests on nutrient-rich organic soils".

\section{REFERENCES}

1. Burrough P. A., van Gaans P. F. M., Hootsmans R. 1997. Continuous classification in soil survey: spatial correlation, confusion and boundaries. Geoderma, Vol. 77, Iss. 2-4, pp. 115-135. https://doi.org/10.1016/S0016-7061(97)00018-9

2. Christensen N. L., Bartuska A. M., Brown J. H., Carpenter S., D’Antonio C., Francis R., Franklin J., MacMahon J.A., Noss R.F., Parsons D.J., Peterson C.H., Turner M.G., Woodmansee R.G. 1996. The Report of the Ecological Society of America Committee on the Scientific Basis for Ecosystem Management. Ecological Applications, Vol. 6(3), pp. 665-691. https://doi.org/10.2307/2269460

3. Haapalehto T.O., Vasander H., Jauhiainen S., Tahvanainen T., Kotiaho,J. S. 2011. The effects of peatland restoration on water table depth, elemental concentrations, and vegetation: 10 years of changes. Restoration Ecology, Vol. 19, Iss. 5, pp. 587 - 598. https://doi.org/10.1111/j.1526-100X.2010.00704.X

4. Handmer J., Honda Y., Kundzewicz Z.W., Arnell N., Benito G., Hatfield J., Mohamed I.F., Peduzzi P., Wu S., Sherstyukov B., Takahashi K., Yan Z. 2012. Changes in impacts of climate extremes: human systems and ecosystems. In: Field, C.B., Barros, V., Stocker, T.F., Qin, D., Dokken, D.J., Ebi, K.L., Mastrandrea, M.D., Mach, K.J., Plattner, G. -K., Allen, S.K., Tignor, M., Midgley, P.M. (eds.), Managing the Risks of Extreme Events and Disasters to Advance Climate Change Adaptation. A Special Report of Working Groups I and II of the Intergovernmental Panel on Climate Change (IPCC), pp. 231-290.

5. Holmgren P. 1994. Multiple flow direction algorithms for runoff modelling in grid based elevation models: An empirical evaluation. Hydrological Processes, Vol. 8(4), pp. 327-334. https://doi.org/10.1002/hyp.3360080405

6. Ivanovs J., Lupikis A. 2018. Identification of wet areas in forest using remote sensing data. Agronomy Research, Vol. 16(5), pp. 2049-2055. 
7. Jencso K. G., McGlynn B. L., Gooseff M. N., Wondzell S. M., Bencala K. E., Marshall L. A. 2009. Hydrologic connectivity between landscapes and streams: Transferring reach- and plot-scale understanding to the catchment scale. Water Resources Research, Vol. 45, Iss. 4, pp. 1-16. https://doi.org/10.1029/2008WR007225

8. Kovats R.S., Valentini R., Bouwer L.M., Georgopoulou E., Jacob D., Martin E., Rounsevell M., Soussana J.F. 2014. Europe. In: Barros, V.R., Field, C.B., Dokken, D.J., Mastrandrea, M.D., Mach, K.J., Bilir, T.E., Chatterjee, M., Ebi, K.L., Estrada, Y.O., Genova, R.C., Girma, B., Kissel, E.S., Levy, A.N., MacCracken, S., Mastrandrea, P.R., White, L.L (eds.), Climate Change 2014: Impacts, Adaptation, and Vulnerability. Part B: Regional Aspects. Contribution of Working Group II to the Fifth Assessment Report of the Intergovernmental Panel on Climate Change, pp. 1267-1326. Cambridge: Cambridge University Press.

9. Kozlowski T.T. 2002. Physiological-ecological impacts of flooding on riparian forest ecosystems. Wetlands, Vol. $22(3)$, pp. 550-561. https://doi.org/10.1672/0277-5212(2002)022[0550:PEIOFO]2.0.CO;2

10. Latvian Geospatial information agency. 2017. Aerolāzerskenēšanas dati, to apstrāde un pielietojums. Fotogrammetrijas diena. (In Latvian).

11. Lohmus A., Remm L., Rannap R. 2015. Just a Ditch in Forest? Reconsidering Draining in the Context of Sustainable Forest Management. BioScience, Vol. 65, Iss. 11, pp. 1066-1076. https://doi.org/10.1093/biosci/biv136

12. Moore I. D., Grayson R. B., Ladson A. R. 1991. Digital terrain modelling: A review of hydrological, geomorphological, and biological applications. Hydrological Processes, Vol. 5(1), pp. 3-30. https://doi.org/10.1002/hyp.3360050103

13. Peltomaa R. 2007. Drainage of forests in Finland. Irrigation and Drainage, Vol. 56, pp. 151-159. https://doi.org/10.1002/ird.334

14. Piirainen S., Finér L., Andersson E., Belova O., Čiuldiené D., Futter M., Gil W., Glazko Z., Hiltunen T., Högbom L., Janek M., Joensuu S., Jägrud L., Lībiete Z., Lode E., Löfgren S., Pierzgalski E., Ring E., Zariņš J., Thorell D. 2017. Meža nosusināšana un ūdens aizsardzība Baltijas jūras reǵiona valstīs - pašreizējās zināšanas, metodes un attīstības virzieni (In Latvian).

15. Skaggs R.W., Tian S., Chescheir G.M., Amatya D.M., Youssef M.A. 2016. Forest drainage. Forest Hydrology: Processes, Management and Assessment. United Kingdom, CABI Publishers, pp. 124-140. https://doi.org/10.1079/9781780646602.0124

16. Wang L., Liu H. 2006. An efficient method for identifying and filling surface depressions in digital elevation models for hydrologic analysis and modelling. International Journal of Geographical Information Science, Vol. 20, Iss. 2, pp. $193-213$. https://doi.org/10.1080/13658810500433453

17. Zālītis P., Jansons J., Indriksons A. 2013. Mežaudžu parametri hidrotehniski meliorētajos mežos pēdējos piecdesmit gados. Mežzinātne, No. 27(60):, pp. 36-66. (In Latvian)

18. Zinko U., Seibert J., Dynesius M., Nilsson, C. 2005. Plant species numbers predicted by a topography-based groundwater flow index. Ecosystems, Vol. 8, Iss. 4, pp. 430-441. https://doi.org/10.1007/s10021-003-0125-0 